UDC 657.1:005.53

\title{
THE IMPORTANCE OF FINANCIAL STATEMENT RESULTS FOR BUSINESS MANAGEMENT SOLUTIONS
}

\author{
(C) Šidlauskienė Danguolè \\ Marijampole college (Marijampole, Lithuania) \\ E-mail: danguole.sidlauskiene@ mkolegija.lt, ORCID: 000-0002-9154-2934 \\ (C) Birutė Petrošienė \\ Marijampole college (Marijampole, Lithuania) \\ E-mail: birute.petrosiene @ mkolegija.lt, ORCID: 0000-0002-5160-8249 \\ (C) Gabrevičienė Aušra \\ Marijampole college (Marijampole, Lithuania) \\ E-mail: ausra.gabreviciene@mkolegija.lt, ORCID: 0000-0001-7685-1440
}

\begin{abstract}
Information is a very important factor in various fields of activity of the contemporary people. In any economic activities as well as in the activities of the economic entity the information is used for decision-making. The information may be economic, legal, scientific and otherwise, but in order to manage economic processes the most important is economic information. The greatest part of this information is provided by accounting both financial and management.
\end{abstract}

In every company as in a separate accounting unit, a lot of economic transactions and events occur over the year, constantly recording the movement of money, the amount of revenue and costs. Periodically, in the activities of enterprises, institutions or organizations it is necessary to summarise all the available economic information and calculate performance results, to show the remains of assets, equity and liabilities. Financial statements of the company in the market economy conditions is the main source of information about the assets, liabilities, capital, profits and cash flows.

Accumulated and grouped financial information of companies, institutions, or organizations in the form of financial statements periodically, but not less often than at the end of the financial year, is is presented to all users who are interested in it, since the annual financial accounts must be provided by all companies, enterprises or organisations with legal status. Many Lithuanian authors, dealing with financial statements, note that the current forms used for financial statements do not provide sufficient information to meet the users' needs in constant competitive conditions and, therefore, there are a lot of discussions how these statements could be improved.

When analysing financial accountability, problematic aspects of assessment of financial statements elements are faced. Both Lithuanian and foreign authors pay little attention to the assessment analysis of financial statement elements, because for businesses both in Lithuania and abroad it is rather complicated to assess properly the elements of the financial statements by assessment methods available in the literature in such a way that they would reflect the state of the company truly and correctly.

This time, however, the figures in the financial statements is one of the most important sources of information for economic state assessment of companies, enterprises or organisations and for business management solutions. Accounting professionals and other users, when analysing the financial statements, may form opinions and draw conclusions about the profitability of the core business of the analysed entity, the ability to cover its short-term and long-term liabilities, as well as about long-term and short-term assets, product manufacturing and sales situation and changes during the reporting period, and relying on these data decide on the reliability of the company, development and investment opportunities.

Key words: financial accountability of the company, balance sheet, profit (loss) statement, cash flow statement, statement of change in equity, reporting period, explanatory note, accounting policy.

\section{INTRODUCTION}

The relevance of the theme. The information presented in the financial statements must be reliable, comprehensive and easily accessible to internal and external users.
The problem of research. It is very important that the statements of financial accountability would be truly made and carry out its purpose. Correctly gathered systematic accounting information allows to account assets, capital, income and expenses properly. Otherwise, the wrong information will

The importance of financial statement results for business management solutions 
give distorted results of analysis and its users will make false business management decisions.

The aim of the article - to examine the principles of financial statement formation and to assess the significance of financial accountability results for business management decision-making.

The objectives of the research - to examine the principles and requirements of financial statement formation; to examine methodology of financial statement formation; to assess the importance of financial accountability for business management solutions.

The object of the research - financial statements of the entity.

Research methods: analysis of scientific literature, including a comparison of the theoretical statements, methods of comparison and summarizing.

\section{FINANCIAL STATEMENTS, ITS PREPARATION AND INFORMATION SUBMISSION TO USERS}

The final stage of financial accounting reports is a preparation of group reports, known as financial accountability. Financial statements is the model of economic unit. Even though the accountability does not present the comprehensive true view of business condition, it is the best possible test for accounting clerks to reach it (Brukštaitienè d. 2008, p. 102).

In accounting, information collection process may not be infinite, at the end of the set period it must be completed. At the end of the accounting period all the results have to be assessed of this period and discussed follow-up plans and activities (Bukevičius, Žaptorius 2008).

Mackevičius (2006, p. 14) describes the necessity of financial statements preparation as the accounting data of the enterprise's financial situation, performance results, cash flows and periodic preparation of other financial issues in the established form in order to meet the needs of information users.

In business accounting standards, the objective of financial accountability is developed to meet the needs of information users and receive the correct information about the company's financial situation, performance results and cash flows (1 BAS).

Bagdžiūniene, when formulating the objective of financial accountability, distinguishes objectives groups, i.e. primary and secondary objectives. The objectives, defined by the author according to their purport, overlap with those of other authors. According to Bagdžiūniene (2008, p. 13) the main objective of financial accountability is reliable submission of information about the company's financial situation, financial liabilities, money flows, and setting of additional objectives is related to useful information submition for various decision-making.

According to all objectives of financial accountability it is possible to state that financial accountability should reflect the correct information about the company's financial situation and performance results, as well as to provide the necessary information to internal and external users and reveal important information about the significant events that have occurred during the accounting period (Waters 2003).

In general, for financial accountability formation all accounting system data are used, i.e. financial accounting data, and in some cases, management accounting. When forming financial statements, the accounting data, reflected in journals, books, records, and other accounting registers are summarized and systematized in a certain way, in accordance with General Accounting principles, International and National Business Accounting Standards or other regulatory acts (2006 Mackevičius, p. 24).

The organization of financial accounting and financial statement preparation procedures are regulated by the laws of LR, International Business Accounting Standards, and national business accounting standards and accounting policies prepared by the company. This regulation demonstrates that great attention is paid to financial accounting, since this is the source of submission of information of great importance necessary for business management decision-making.

In 2001, November 6th, the Law on Accounting of LR was passed, which regulate general accounting principles, its organization and management requirements. This law states, that the whole of accounting methods in accordance with the legislation laid down, which regulates accounting management and formation of financial statements, determines the legal form of the entity, the entity's size, the nature of the activities and the form of ownership. This law was replaced in 2015, May 15th, it is relevant when preparing financial accountability in 2016.

In the same period, another very important law was passed - the Law on Company's Financial Accountability of LR, which regulates the company's financial accountability, the requirement to conduct audits of financial statements, preparation of annual report, responsibility for anouncement of financial statements. This law was replaced in 2015, May 15th, it is relevant when preparing financial accountability in 2016.

The Law on Company Groups' Consolidated Financial Accountability of Lithuanian Republic regulates consolidated financial accountability formation, its confirmation, anouncement,

(C) Šidlauskienė Danguolè, Birutė Petrošienè, Gabrevičienè Aušra, 2017 
consolidated annual report preparation, audit conduct and determines other requirements for companies, preparing consolidated financial accountability. The law is applied to stock companies and joined stock companies, able to make a direct or indirect decisive impact on one or more profit entities, as well as banks, other credit institutions and insurance businesses. This law was replaced in 2015, May 15th, it is relevant when preparing financial accountability in 2016 .

International Accounting Standards are published by the International Accounting Standards Committee, established on June 29th, 1973. This is an independent organization, preparing and improving international accounting standards. Accounting rules of each free market country are based on international accounting standards and general accounting standards. Commission Regulation (EC) No 1126/2008, November 3rd, 2008, adopting certain international accounting standards in accordance with European Parliament and Council Regulation (EC) No. 1606, determines accounting management in accordance with the 1st and the 8th International Accounting Standards provisions (Waters, 2003, p. 412).

National Business accounting standards systematize the information on accounting, prepared financial statements, accounting organisation. The office of audit and accounting, in accordance with the Law of LR on Accounting, Article 3, develops, confirms and publishes Business Accounting standards (BAS). BAS is prepared by the office of audit and accounting. Amendments and additions to the standards, and a new edition is published in the "Official Gazette".

Accounting standards are the rules of assets, equity and liabilities assessment, income and expenses recognition and registration in accounting according to which the financial statements is prepared.

Business accounting standards changed the Government's resolutions of the Republic of Lithuania and the Ministry of Finance, that have regulated financial accounting management before the entry into force business accounting standards.

Some provisions of many business accounting standards have been reviewed and amended not once. Currently, a large part of the accounting standards is reviewed and replaced, related to financial statements as well. They came into force from January 1st, 2016 onwards.

The procedures and requirements of financial statement formation, according to which the financial statements would be possible to compare to the same company's previous periods, and to other companies' financial statements, are regulated by 1 st business accounting standard "Financial accountability" and 1st international accounting standard "Submission of financial statements". These documents determine the procedures composition of financial statements presentation and general content requirements.

Financial statements formation is the final phase of accounting process. The purpose of the financial statements is to meet the needs of information users to get complete and correct information about the company's financial situation, performance results and cash flows in order to make the right decisions for business management. The size and the structure of the company's assets, equity and liabilities before the date of the financial statements formation, are presented in the balance sheet. During the accounting period, the company's earned revenue and incurred costs (loss) are presented in the profit (loss) statement. Changes in equity, the events occured during the accounting period, are presented in the equity changes statement. The cash flow statement presents classified cash flows according to the types of the company's activities - operating, investing and financing activities. The explanatory note provides additional information on the indicators of financial statements, which may be supplemented by non financial information as well. The information on financial statements is in the public domain, available to both internal and external users and allows them to understand better the specifics of the company's activities, the values of the indicators, to assess the company's financial situation and make reasonable decisions (Bartaška at al, 2009, p. 125).

The basic form of accountability, which is prepared and provided by all companies, is financial accountability. This accountability is prepared in accordance with the generalized data of the company's financial year, however, taking into consideration the legal acts, regulating accountability formation and submission and/or the needs of the executives, the financial accountability may be prepared more frequently than once a year and be provided to the public or not (Kanapickiene, et al., 2008, p. 214).

When forming financial accountability, tax accountability is formed as well, which is provided to the tax administrator - the National Tax Inspection, social insurance institutions, etc. (Bukevičius, Žaptorius, 2008). There is a connection between financial and tax accountability of the company. This connection appears in the financial and tax accountability of the company, showing the estimated profit tax and its change, when taxable income is adjusted (Juškauskas, 2007, p. 142).

If required, along with the financial accountability, statistical and special purpose

The importance of financial statement results for business management solutions 
accountability may be formed. Statistical accountability is provided to the state statistical enterprises, and the special purpose accountability, covering a very wide scope of statements, most frequently provides information to all management staff of the company, and in these statements management accounting data is provided. They may be very numerous and diverse, as each manager requires specific information describing his bar. The various special-purpose accountability can be presented to a number of external users as well (Bukevičius, Žaptorius, 2008, p. 161).

When forming financial statements, it is necessary to provide the following information, which corresponds to the four characteristics: understandability, usefulness, significance and reliability (Brukšaitiene, 2008), i.e., in financial statement reports the information must be presented in a clear and understandable form, that information users would be able to make the right decisions, and the data itself must be neutral, related and significant in order to provide a fair and reliable information on the financial situation of the company, assets, equity, liabilities, performance results and cash flows, because non-submission of significant or non-disclosure of it may influence on the decisions of financial accountability information users (1 BAS).

In order that all articles of the financial statements would be assessed reliably, they should be assessed in the following ways: cost price of acquisition, fair value, the value of the current cost, realisable value, possible net realisable value or present value, amortized cost price and cost price of use. According to Mackevičius (2006) most frequently financial elements are assessed at the acquisition cost. This assessment can be combined with other techniques, for example, stocks can be recorded at acquisition cost, and the statements show the acquisition cost or net realisable value, at the value that is lower. Assessment methods of all other financial statements elements may be chosen by the companies, it is important that the choices of methods would be reasonable in the accounting policy and conform with the provisions of business accounting standards.

Ten general accounting principles are distinguished according to 1 BAS. The basic principle, following which the financial accountability must be made, is the accrual principle, i.e. in accordance with this principle, on the basis of formed accounting data, not then, when income and expenses in the statement are recognised, when the money is received or paid, but then, when income is earned and expenses are experienced (an income can be the same as the obtaining of money) (1 BAS). The annual financial accountability has to be prepared in accordance with the activity continuation principle as well. It has a very significant influence on both the revenue and costs, and for the asset assessment. On the assumption that the activities of the company will continue after finishing of an ordinary accounting period, but will last for a long time in the future, the costs of the accounting period is recognised only for that part of the expenses, which has been alloted to make the income of that period or that cannot be related to any further accounting period. Costs, that will have to earn income in the future, must be capitalized, i.e. recognised as assets that will make income to the company in the coming accounting periods. (Brukšaitiene, 2008, p. 178).

In managing company's accounting it is very important to comply with the corporate principle, which means that the company forming financial accountability is considered as a separate unit of accounting and in financial accountability should be included the assets, equity, liabilities, income, expenses, and cash flows only of that company. In parallel with this principle the company must apply the principles of precautionary and neutrality.

The application of prudence principle in the accounting and accountability indicates that assessing the company's debts and liabilities of the company, as well as predicting the results of the company's activities have to be followed not optimistic but pessimistic forecasts, and the application of neutrality principle would mean that the information provided in the financial statement should be objective and impartial. Its presentation should not depend on the aim of forcing the users of accounting information to adopt an enterprisefriendly solutions (1 BAS).

All accounting information must be shaped in accordance with the principles of stability, comparison and monetary measure as well. On the basis of stability principle the accounting methodology can not be often changed, and information about performance results of different accounting periods of the same or different companies must be possible to compare, allowing the user to identify the advantages, differences, and trends.

Thus, the corporate accounting and financial accountability should be handled and made up in accordance with all financial statement principles, methods and rules mentioned above, various corporate accounting procedures, and methodologies selected from the alternatives presented in the Business Accounting Standards (BAS), International Accounting Standards (IAS), and in corporate accounting policies and information provided in financial statements should comply with all quality requirements. In the

(C) Šidlauskienė Danguolè, Birutė Petrošienė, Gabrevičienė Aušra, 2017 
financial statements the true and fair view of the company's financial situation must be presented, allowing to take relevant business management solutions.

\section{CHANGES IN THE PREPARATION OF FINANCIAL STATEMENTS SINCE JANUARY 1ST, 2016 ONWARDS}

When implementing the Directive 2013/34ES of the European Parliament and Council, June 26th, 2003, the Corporate Financial Accountability Act has been replaced and set out in a new wording. The provisions of the new Act are applied to the preparation of annual financial reports set and annual reports of the company's accounting periods starting on January 1st, 2016 and onwards.

According to the new provisions of Article 4 of this Act, companies are divided into:

- very small;

- small;

- medium-sized and large.

Very small companies are companies, in which at least two of the indicators of the last day of the fiscal year do not exceed the following values:

1) the assets value indicated in the balance sheet - 350000 EUR;

2) sales net income during the financial year 700000 EUR;

3) the average annual number of employees in accordance with the list during financial year -10 employees [10].

Small companies are companies in which at least two of the indicators of the last day of the fiscal year do not exceed the following values:

1) the assets value indicated in the balance sheet - 4000000 EUR;

2) sales net income during the financial year 8 000000 EUR;

3) the average annual number of employees in accordance with the list during financial year -50 employees.

Medium-sized are companies in which at least two of the indicators on the last day of the fiscal year shall not exceed the following values:

1) the assets value indicated in the balance sheet - 20000000 EUR;

2) sales net income during the financial year 40000000 EUR;

3) the average annual number of employees 250 employees.

Large companies are companies in which at least two of the indicators exceed the following values.

These companies have to make financial statements that include the following information:

- assets;

- equity;
- liabilities;

- income and costs;

- cash flows [11].

The absolute majority of the Lithuanian companies instead of four different financial statements since 2016 provide only two: balance sheet, profit-and-loss statement, even the explanatory notes will not be mandatory.

Compared to the previous balance form, in the new form several new articles are singled out: the costs for the following period and accrued income; accruals and income for the next period. It is also, separately are indicated the provisions - type of liabilities, in which the amount or coverage time are not defined.

The income and expenses for the following periods - these are prepayments for continuous services of a certain period. Accrued income and costs - the amount of provided but not paid yet services of continuous nature.

Profit (loss) statement differs from the larger companies analogue statement not only in number of articles, but in the format itself. The EU directive provides for two alternative profit (loss) report formats. One of them - where income and expenses are grouped according to the activities carried out: basic activities, other activities, financial and investment activities, extraordinary items [12].

Other possible form - income and expenses grouping according to their nature. Initially all types of income are listed, followed by types of expenses. Usually micro-companies develop this format for profit-and-loss statements.

\section{CONCLUSIONS}

1. The development of financial statements are regulated by: the Law on Accounting of LR, the Law on Financial Accountability of LR, the Standards of Consolidated Financial Accountability Formation, International Business Accounting, the National Business Accounting Standards, the accounting policies set up in the companies.

2. When managing accounting and developinf financial statements, the companies have to follow the general accounting principles: of the company, business continuity of the company; periodicity, stability, monetary measure, accrual, comparison, prudence, neutrality, content supremacy over the form.

3. The main methods for the assessment of the financial statements are as follows: acquisition cost price, current cost value, realisable value, current value.

4. In order to harmonise the accounting records of the different objects, a new version of the Law on Accounting of LR came into force and National Business Accounting Standards were amended 
since January 1st, 2016: the first, third, fourth, fifth, sixth.

5. The formation of financial statements are the final phase of the accounting process. The purpose of the financial statements is to meet the information users" needs to get complete and correct information about the company's financial situation, performance results and cash flows in order to make the right decisions for business management.

\section{Список використаних джерел}

1. Bagdžiūnienè, D. (2008). Finansinè turto apskaita ir finansinès atskaitomybès rengimas. Vilnius: Technika [in Lithuanian].

2. Bartaška, R. ir kt. (2009). Finansinès apskaitos teorija ir praktika. Vilnius: Vilniaus universiteto leidykla [in Lithuanian].

3. Brukštaitienè, D. (2008). Finansinè turto apskaita ir finansinès atskaitomybės rengimas. Vilnius: Technika [in Lithuanian].

4. Bukevičius, J., Žaptorius, J. (2008). Apskaitos pagrindai. Vilnius: Technika Deveikis G., (2010). Tarpinės finansinès atskaitomybès rengimas - nauda ar papildomas rūpestis. Apskaitos ir mokesčių apžvalga. 2010, gegužè. [in Lithuanian].

5. Kanapickienė, R., Rudžionienė, K., Jefimovas B. (2008). Finansinè apskaita. Vilnius: Vilniaus universiteto leidykla [in Lithuanian].

6. Mackevičius, J. (2006). Imonių finansinių ataskaitų informacija: reikšmė, vertinimas, analizė. Informacijos mokslai. 2006. [žiūrèta 2017-09-28] Prieiga per internetą: www. Ceeol.com [in Lithuanian].

7. Waters, D. (2003). Inventory Control and Management. New York: Wileyin [in English].

8. Wisner, J. D. (2011). Principles of Supply Chain Management - A Balanced Approach. Thirded. Mason: CengageLearning [in English].

9. LR audito ir apskaitos tarnyba. 1 verslo apskaitos standartas „Finansinė atskaitomybe்“ [žiūrèta 2017-09-30]. Prieiga per internetąwww.aat.lt [in Lithuanian].

10. Олексенко Р. І. (2013). Філософія ринкових відносин. Становлення та розвиток в Україні в період глобалізації та інформаційної революції : соц - філос. Аналіз. Київ: Знання України. 367 с.

11. Олексенко P.І. (2007). Методичні підходи до формування конкурентоспроможності підприємства // Інвестиції: практика та досвід. 2007. №19. С. 27-30.

12. Олексенко Р. І. (2015). Вплив комунікацій на ціннісні орієнтири особистості // Гуманітарний вісник Запорізької державної інженерної академії : зб. наук. пр. / М-во освіти і науки України, Запорізька державна інженерна академія. Запоріжжя. Вип. 62. С. 65-73.

\section{REFERENCES}

1. Bagdžiūnienè, D. (2008). Finansinè turto apskaita ir finansinès atskaitomybės rengimas. Vilnius: Technika [in Lithuanian].

2. Bartaška, R. ir kt. (2009). Finansinès apskaitos teorija ir praktika. Vilnius: Vilniaus universiteto leidykla [in Lithuanian].

3. Brukštaitienè, D. (2008). Finansinè turto apskaita ir finansinès atskaitomybès rengimas. Vilnius: Technika [in Lithuanian].

4. Bukevičius, J., Žaptorius, J. (2008). Apskaitos pagrindai. Vilnius: Technika Deveikis G., (2010). Tarpinès finansinès atskaitomybès rengimas - nauda ar papildomas rūpestis. Apskaitos ir mokesčių apžvalga. 2010, gegužè. [in Lithuanian].

5. Kanapickienė, R., Rudžionienè, K., Jefimovas B. (2008). Finansinė apskaita. Vilnius: Vilniaus universiteto leidykla [in Lithuanian].

6. Mackevičius, J. (2006). Imonių finansinių ataskaitų informacija: reikšmè, vertinimas, analizè. Informacijos mokslai. 2006. [žiūrèta 2017-09-28] Prieiga per internetą: www. Ceeol.com [in Lithuanian].

7. Waters, D. (2003). Inventory Control and Management. New York: Wileyin [in English].

8. Wisner, J. D. (2011). Principles of Supply Chain Management - A Balanced Approach. Thirded. Mason: CengageLearning [in English].

9. LR audito ir apskaitos tarnyba. 1 verslo apskaitos standartas „Finansinė atskaitomybe்“ [žiūrèta 2017-09-30]. Prieiga per internetąwww.aat.lt [in Lithuanian].

10. Oleksenko, R.I. (2013). Philosophy of market relations. Formation and development in Ukraine in the period of globalization and the information revolution: social-philosophical analysis. Kiev: Ukraine's Knowledge. 367 s. [in Ukrainian].

11. Oleksenko, R.I. (2007). Methodological approaches to formation of competitiveness // Investment: practice and experience. № 19. 27-30 [in Ukrainian].

12. Oleksenko, R.I. (2015). The effect communication on the value guidance of personality // Humanitarian Bulletin of Zaporizhzhia State Engineering Academy: singles Sciences / The Ministry of education and science of Ukraine, Zaporizhzhya State Engineering Academy. Zaporizhzhia : [GS Sciences etc.]. Zaporizhzhi: publishing of ZDIA. Issue 62. 65-73 [in Ukrainian].

(C) Šidlauskienė Danguolè, Birutė Petrošienè, Gabrevičienė Aušra, 2017 
ШІДЛАУСКЕНЕ, ДАНГОУЛЕ - лектор Маріямпольської колегії (Маріямполь, Литва)

E-mail: danguole.sidlauskiene@mkolegija.lt, ORCID: 000-0002-9154-2934

БІРУТЕ, ПЯТРОШЕНЕ - лектор Маріямпольської колегії (Маріямполь, Литва)

E-mail: birute.petrosiene@ mkolegija.lt, ORCID: 0000-0002-5160-8249

ГАБРЯВІЧЕНЕ, АУШРА - лектор Маріямпольської колегії (Маріямполь, Литва)

E-mail: ausra.gabreviciene@mkolegija.lt, ORCID: 0000-0001-7685-1440

\section{АКТУАЛЬНІСТЬ РЕЗУЛЬТАТІВ ФІНАНСОВОЇ ЗВІТНОСТІ ДЛЯ ПРИЙНЯТТЯ БІЗНЕС-РІШЕНЬ}

Анотація. Інформація постає впливовим фактором у різних сферах діяльності сучасних людей. В будьякій господарській діяльності, а також у діяльності суб'єкта господарювання інформачія використовується для прийняття рішень. Інформація може носити економічний, правовий, науковий та інший характер, але для управління економічними прочесами найважливішою $є$ економічна інформація. Найбільша частина иієї інформації забезпечується обліком як фінансової діяльності, так і управлінської. У кожній компанії, як в окремій бухгалтерській одиниці, протягом року відбуваються багато економічних операцій, щฺо постійно фіксують рух грошей, суму доходів і витрат. Періодично в діяльності підприємств, установ або організацій необхідно підсумувати всю наявну економічну інформацію та підрахувати результати діяльності, щцоб показати залишки активів, власного капіталу та зобов'язань. Фінансові звіти компанії в умовах ринкової економіки є основним джерелом інформації про активи, зобов'язання, капітал, прибуток та грошові потоки. Акумульована та згрупована фінансова інформаџія компаній, установ чи організацій в формі фінансової звітності періодично, але не рідше, ніж на кінець фінансового року, представлена всім користувачам, які зацікавлені в иьому, оскільки щорічні фінансові рахунки повинні надаватися усіма компаніями, підприємствами або організаціями, щуо мають юридичий статус. Багато литовських авторів, які досліджують проблеми фінансової звітності, зазначають той факт, щэо поточні форми,які наразі використовуються, не забезпечують достатньої інформації для задоволення потреб користувачів у стійких конкурентних умовах. Тому існує багато дискусій щуодо питання, як зазначені документи щзодо звітності можна вдосконалити. Аналізуючи фінансову звітність, дослідники стикаються з проблемними аспектами оцінки фінансових звітів. Як литовські, так $і$ зарубіжні автори мало уваги приділяють оцінці аналізу елементів фінансової звітності, оскільки для підприсмств як в Литві, так $і$ за кордоном досить складно правильно оцінити елементи фінансової звітності доступними в літературі методами таким чином, щоб вони коректно відображали стан справ. Проте циифри в фінансовій звітності є одним з найважливіших джерел інформації для економічної оцінки підприємств, організацій та рішень з управління бізнесом. Фахівці з бухгалтерського обліку та інші користувачі при аналізі фінансової звітності можуть аналізувати та робити висновки про рентабельність основного бізнесу компанії,цо вивчається, щодо ї̈ можливості покриття своїх короткострокових та довгострокових зобов'язань, щчодо ї̈ активів, ситуаиії з виробниитвом та продажем товару та відстежувати зміни протягом звітного періоду, $i$, спираючись на ичі дані, визначають надійність компанії, можливості ї̈ розвитку та інвестиції.

Ключові слова: фінансова звітність підприємства, баланс, звіт про прибутки (збитки), звіт про рух грошових коштів, звіт про зміни у капіталі, звітний період, пояснювальна записка, облікова політика

Стаття рекомендована до публікації доктором РhD соиіальних наук (менеджмент), доцент, зав. кафедри бізнесу та економіки Андрюкайтене, Регіною Маріямпольська колегія (Маріямполь, Литва)

Шідлаускене, Дангоуле - лектор Маріямпольської колегії (Маріямполь, Литва)

E-mail: danguole.sidlauskiene@ mkolegija.lt, ORCID: 000-0002-9154-2934

Біруте, Пятрошене - лектор Маріямпольської колегії (Маріямполь, Литва)

E-mail: birute.petrosiene@ mkolegija.lt, ORCID: 0000-0002-5160-8249

Габрявічене, Аушра - лектор Маріямпольської колегії (Маріямполь, Литв)

E-mail: ausra.gabreviciene @ mkolegija.lt, ORCID: 0000-0001-7685-1440 